\title{
VIRTUAL REALITY INTERVENTION TO REDUCE CHILD ANXIETY ON DENTAL CARE: A SYSTEMATIC REVIEW
}

\author{
Ista Ardiagahayu Praptidina'), Pujiyanto²) \\ ${ }^{1)}$ Masters Program in Public Health, Universitas Indonesia \\ 2)Department of Health Policy Administration, Faculty of Public Health, \\ Universitas Indonesia
}

\begin{abstract}
Background: Unpleasant early dental experience pain and anxiety can result in several negative consequences, such as dental fear, uncooperative behavior, and general dissatisfaction of the patients with dental care. Several techniques may be useful to reduce pain and anxiety in child patients during dental procedures.This study aimed to review systematically the effectiveness of virtual reality intervention to reduce child anxiety on dental care.

Subjects and Method: A systematic review was conducted by searching published articles from 2014 to 2019 from databases included Proquest, Scopus, Science Direct, and Springer Link. The keywords for this review were "Virtual Reality", "Dental Anxiety", "Dental Phobia", "Children", and "Pain Perception". The inclusion criteria were English, open access, and dental health. The independent variable was virtual reality intervention. The dependent variable was fear and anxiety. After review process 5 articles from USA, Holland, UK, and 2 articles from India, were included in this review.

Results: After intervention, fear and anxiety scores in pre-dental care were lower in children who were intervened than those who were not, and it was statistically significant $(p<0.001)$. After intervention, fear and anxiety scores in post-dental care were lower in children who were intervened than those who were not, and it was statistically significant $(\mathrm{p}<0.001)$.

Conclusion: Virtual reality is an effective non-pharmacological intervention to reduce fear and anxiety in children during dental care.
\end{abstract}

Keywords: virtual reality, fear, anxiety, dental care, children.

\section{Correspondence:}

Ista Ardiagahayu Praptidina. Masters Program in Public Health, Universitas Indonesia, Depok, West Java. Email: istaardiya@gmail.com. Mobile: 082276973102.

\section{BACKGROUND}

Indonesian Ministry of Health's data and information Centerin 2007 reported that 23\% of Indonesians had dental and mouth problems and only $30 \%$ received treatment. In 2013 , there were $26 \%$ of Indonesia's population having dental and mouth problems and only $31 \%$ received treatment.

The latest Basic Health Research data in 2018 recorded the proportion of dental and mouth problems in the Indonesian population of $57.6 \%$ and those receiving services from medical staff was only $10.2 \%$, in the Basic Health Research, it also mentioned that 93\% of early childhood which was in the age range of 5-6 years old had caries or cavities. This mean that only $7 \%$ of children in Indo- nesia were free from dental caries problems.

Fear is a condition that is generally adaptive to concerns or threats or hazards that may occur immediately, while anxiety almost have the same meaning as fear but is caused by threats that are not specific and less predictable. Fear and anxiety in children when dental treatment will have a bad influence on the results of care given (Tiwari, 2015).

Anxiety in children during dental care made them less likely to be cooperative so that it caused difficulties when receiving dental care. Children tend to avoid or delay treatment so that it can result in decreased dental health (Gao and Hamzah, 2013). Studies also showed that children with high 
levels of anxiety have more caries than children with low levels of anxiety (Porrit, 2012). This anxiety during childhood can last into adulthood and was a reason to avoid dental visits for oral health care as an adult.

Behavioral management to overcome child anxiety can be divided into pharmacological and non-pharmacological. In the nonpharmacological section methods such as non-verbal education, voice control, tell show do and distraction (Robert, 2010). Distraction is a technique commonly used in dental care that is useful to divert children's attention from the perception of fear and anxiety when undergoing dental care procedures. There are two methods of distraction commonly used in dental care, namely audio distraction like using music and audiovisual distraction such as the use of virtual reality (Aminabadi, 2012).

Virtual reality is a three-dimensional simulation technology that can be used interactively through a computer. During the last two decades, virtual reality has been widely used in various business practices as an effective and efficient tool to prevent emotional disorders such as anxiety and physical disabilities in rehabilitation processes (Jengic, 2016).

The system found in virtual reality technology is in the form of repeated interactions and training in order to attract attention and also motivate children. Virtual reality has also been applied to assess cognitive abilities and also neurocognitive rehabilitation in patients with special needs such as stroke patients (Laver, 2012). Whereas in the dental treatment, the use of virtual reality can be used to overcome anxiety and anxiety in patients during action on dental care (TanjaDijkstra, 2014). Therefore, the purpose of this study was to determine the effectiveness of virtual reality interventions in reducing fear and anxiety in children during dental care.

\section{SUBJECTS AND METHOD}

\section{Study Design}

In this article, the method used in this systematic review was PRISMA - P 2015 (Preferred reporting items for systematic reviews and meta-analysis protocols, 2015) (Mother et al., 2015). The study searched through three databases namely ProQuest, Scopus and Science Direct

This study used the keywords "Virtual Reality", "Dental Anxiety", "Dental Phobia", "Children", "Pain Perception". The journals were from January 2015 - April 2019.

\section{Inclusion and Exclusion Criteria}

The inclusion criteria used in this study were journal articles published in the last 7 years, using English, there were complete text articles, using randomized control trials (RCT) study design, with the scope of dental health, psychology and public health. While the exclusion criteria were journals that were not in English and were published before January 2013.

By using the keywords "virtual reality" AND "dental anxiety" AND "children" AND "pain perception" from 3 databases, it received 835 articles. Then it was narrowed by a span of 5 years and in dentistry, public health and psychology produced 273. Then selected again by looking at the title and reading abstracts one by one to get a randomized control trial study getting 26 , then in the final result, it obtained 7 relevant articles (Figure 1). 


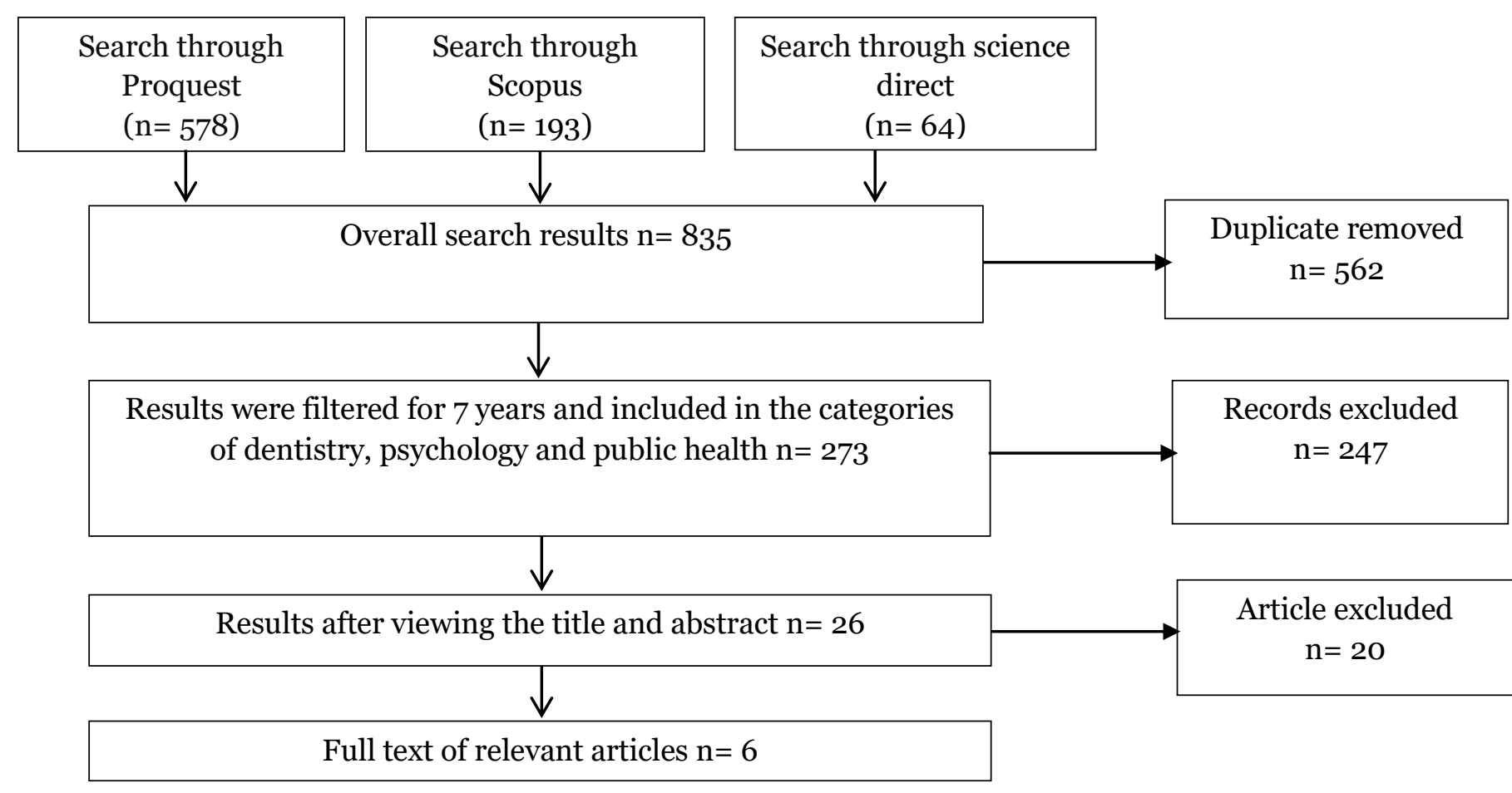

Figure 1. PRISMA flow diagram

\section{RESULTS}

From 3 databases, 835 articles were obtained, there were 6 articles that fulfill the criteria (Figure 1). From the 6 articles obtained, it was found that virtual reality has a significant relationship $(\mathrm{p}=0.001)$ by reducing anxiety in dental care, especially from 6 articles that can reduce children's anxiety during dental treatment in the form of anesthesia during tooth extraction, root canal treatment in molar teeth, dental fillings, tartar cleaning in adolescents and also one visit pulpotomy in milk teeth. There were searches in India, the United States and also Saudi Arabia. The second picture show a summary that has been observed from 6 articles on virtual reality interventions on dental care.

\section{DISCUSSIONS}

Pain or fear and anxiety are unpleasant feelings and emotional experiences. Management strategies that aim to reduce anxiety and fear when caring for a child's teeth were divided into 2 categories. The first was about behavioral techniques such as tell-show do, hypnotism and distraction (Aminabadi, 2012). Distraction is the most effective nonpharmacological behavior management technique and is very easy to use. This distraction application is based on the assumption that fear or pain perception has a large psychological component in terms of the amount of attention directed at stimulation that regulates the perception of pain, fear or anxiety (Shafi, 2015).

The development of wireless audiovisual glasses was increasingly easy to use, convenient and inexpensive for dentists and for children to provide further opportunities for their dental care. In recent years, there has been an increase in virtual reality behavior. This application was better compared to traditional distraction because it offered a deeper image using a headset so that it can project images right in front of the user's eyes and can block or block the real world either visually, auditory or both (Asvanund, 2015). 
Table 1. Summary of Virtual Reality Interventions Overcoming Children's Anxiety in Dental Care

\begin{tabular}{|c|c|c|c|c|c|c|c|c|c|}
\hline No & Study & Tittle & Place & $\begin{array}{c}\text { Dental } \\
\text { treatment }\end{array}$ & $\begin{array}{l}\text { Duration } \\
\text { interven- } \\
\text { tion }\end{array}$ & $\begin{array}{c}\text { Sample } \\
\text { size }\end{array}$ & $\begin{array}{l}\text { Control } \\
\text { groups }\end{array}$ & $\begin{array}{l}\text { Intervention } \\
\text { group }\end{array}$ & $\begin{array}{c}\text { Outcome } \\
\text { measurement }\end{array}$ \\
\hline 1 & $\begin{array}{l}\text { Khanapur } \\
\text { kari et al. } \\
\text { (2018) }\end{array}$ & $\begin{array}{l}\text { Effect of virtual reality } \\
\text { distraction on pain and } \\
\text { anxiety during local } \\
\text { anesthesia injection in } \\
\text { children - a randomized } \\
\text { controlled cross over } \\
\text { clinical study }\end{array}$ & India & $\begin{array}{l}\text { Patching with } \\
\text { local anesthesia }\end{array}$ & 3x session & $\begin{array}{l}40 \\
\text { children } \\
\text { aged 4-8 } \\
\text { years } \\
\text { old }\end{array}$ & $\begin{array}{l}\text { Application of } \\
\text { local anesthesia } \\
\text { without any } \\
\text { distraction is } \\
\text { then performed } \\
\text { patching }\end{array}$ & $\begin{array}{l}\text { Google } \\
\text { distraction use } \\
\text { virtual reality } \\
\text { when local } \\
\text { anesthetics are } \\
\text { performed }\end{array}$ & $\begin{array}{l}\text { Baseline anxiety is } \\
\text { measured by heart } \\
\text { rate, spo2 and } \\
\text { vpt/Venham picture } \\
\text { test } \\
\text { Local anesthesia is } \\
\text { measured with } \\
\text { venham's clinical } \\
\text { rating scale / vrs and } \\
\text { wong baker (WB) } \\
\text { faces pain scale }\end{array}$ \\
\hline 2 & $\begin{array}{l}\text { Niharika } \\
\text { et al. } \\
\text { (2018) }\end{array}$ & $\begin{array}{l}\text { Effects of distractions } \\
\text { using virtual reality } \\
\text { technology on pain } \\
\text { perception and anxiety } \\
\text { levels in children during } \\
\text { pulp therapy of primary } \\
\text { molars }\end{array}$ & India & $\begin{array}{l}\text { Treatment of } \\
\text { pulp in wisdom } \\
\text { teeth (pulp } \\
\text { therapy) }\end{array}$ & $\begin{array}{l}3 \mathrm{x} \text { of pulp } \\
\text { treatment } \\
\text { in sequence }\end{array}$ & $\begin{array}{l}40 \\
\text { children } \\
\text { aged 4-8 } \\
\text { years } \\
\text { old }\end{array}$ & $\begin{array}{l}\text { Use tell - show } \\
\text { - do technique }\end{array}$ & $\begin{array}{l}\text { Intervention } \\
\text { using virtual } \\
\text { reality tools }\end{array}$ & $\begin{array}{l}\text { Wong baker faces } \\
\text { pain rating scale } \\
\text { MCDAS / modified } \\
\text { child dental anxiety } \\
\text { scale }\end{array}$ \\
\hline 3 & $\begin{array}{l}\text { Barrios et } \\
\text { al. (2015) }\end{array}$ & $\begin{array}{l}\text { The use of immersive } \\
\text { visualization for the } \\
\text { control of dental anxiety } \\
\text { during oral debridement }\end{array}$ & USA & $\begin{array}{l}\text { Perform oral } \\
\text { prophylaxis, } \\
\text { namely a } \\
\text { thorough } \\
\text { examination of } \\
\text { caries, calculus } \\
\text { and periodontal } \\
\text { tissue. }\end{array}$ & $\begin{array}{l}3 x \text { session } \\
\text { of } \\
\text { treatment }\end{array}$ & $\begin{array}{l}30 \\
\text { children }\end{array}$ & $\begin{array}{l}\text { Done without } \\
\text { intervention in } \\
\text { the use of VR } \\
\text { when } \\
\text { prophylactically } \\
\text { done } \\
\text { thoroughly }\end{array}$ & $\begin{array}{l}\text { Intervention } \\
\text { using virtual } \\
\text { reality tools }\end{array}$ & $\begin{array}{l}\text { DAS-R to see anxiety } \\
\text { level } \\
\text { - Likert scale to see } \\
\text { calmness patient } \\
\text { - Opinion survey after } \\
\text { treatment }\end{array}$ \\
\hline 4 & $\begin{array}{l}\text { Furman } \\
\text { et al. } \\
\text { (2019) }\end{array}$ & $\begin{array}{l}\text { virtual reality distraction } \\
\text { for pain control during } \\
\text { periodontal scaling and } \\
\text { root planning } \\
\text { procedures }\end{array}$ & USA & $\begin{array}{l}\text { Scaling and } \\
\text { root canal } \\
\text { treatment in } 3 \\
\text { quadrants of } \\
\text { the oral cavity }\end{array}$ & $\begin{array}{l}3 \text { session in } \\
3 \text { oral } \\
\text { quadrants }\end{array}$ & $\begin{array}{l}38 \\
\text { patients }\end{array}$ & $\begin{array}{l}\text { Done without } \\
\text { intervention } \\
\text { with virtual } \\
\text { reality }\end{array}$ & $\begin{array}{l}\text { Intervention } \\
\text { with virtual } \\
\text { reality }\end{array}$ & $\begin{array}{ll}\text { - } & \text { Vas/visual analog } \\
\text { scale } \\
\text { - } \\
\text { Blood pressure and } \\
\text { pulse } \\
\text { - Questions to patients } \\
\text { after treatment }\end{array}$ \\
\hline 5 & $\begin{array}{l}\text { Shetty et } \\
\text { al. (2019) }\end{array}$ & $\begin{array}{l}\text { Effect of virtual reality } \\
\text { distraction on pain and }\end{array}$ & India & $\begin{array}{l}\text { Single visit } \\
\text { pulpotomy }\end{array}$ & $\begin{array}{l}1 \mathrm{x} \\
\text { treatment }\end{array}$ & $\begin{array}{l}120 \\
\text { children }\end{array}$ & $\begin{array}{l}\text { Done using } \\
\text { behavior }\end{array}$ & $\begin{array}{l}\text { Intervention } \\
\text { with virtual }\end{array}$ & $\begin{array}{l}\text { MCDAS/modified } \\
\text { child dental anxiety }\end{array}$ \\
\hline
\end{tabular}

The $6^{\text {th }}$ International Conference on Public Health Best Western Premier Hotel, Solo, Indonesia, October 23-24, $2019 \mid 588$ https://doi.org/10.26911/the6thicph-FP.05.03 
anxiety during dental

treatment in 5 to 8 year

old children

$6 \quad \mathrm{Al}-$

Khotani

et al.

(2016)

Effect of audiovisual

distraction on children

behavior during dental

treatment: a randomized

controlled clinical trial. aged $5-$

management

Saudi

1. Dental

8 months

examination

with $3 \mathrm{x}$ visit

2. Adjustments

such as

prophylaxis

3. Patching
8 years

old

as tell-show,

voice control,

conversation.

56

reality

Done without

intervention

aged 7-9 with virtual

years reality

old reality scale

- Wong baker faces pain rating scale

Intervention with virtual

- Facial image scale.

- MVARS / Modified Venhams clinical rating of anxiety and cooperative behavior scale

- Vital signs (blood pressure and pulse) 
A concrete example in the dental treatment of children who were 120 children from 4-6 years old that by using virtual reality glasses during local anesthesia can reduce anxiety, was measured by using the face baker pain rating in pain perception and also the size of faces version of the modified child dental anxiety scales (Khanapurkar, 2018).

The same results were obtained from Asvanund et al. (2015) and Niharika et al. (2018), who also reported that distraction with virtual reality techniques was effective in reducing pain as well as anxiety in children during dental care.

The results of this study indicated that the use of virtual reality distraction was more effective than other distractions in reducing pain perception and anxiety levels in children during routine dental care.

Distraction using virtual reality has a significant good effect during dental treatment, because it can enhance positive experiences during treatment and, thus, it can help break the cycle of negative experiences and memories such as fear during dental treatment that can cause anxiety or anxiety in children which resulted in not achieving overall dental health in children.

\section{REFERENCES}

Al-Khotani A, Bello AL, Christidis N (2016). Effects of audiovisual distraction on children's behavior during dental treatment: A randomized controlled clinical trial. Acta Odontologica Scandinavica, 74(6).

Aminabadi N A,Erfanpast L, Sohrabi A, Ghertasi Oskouei S, Naghili A
(2012). The impact of virtual reality distraction on pain and anxiety during dental treatment in 4-6 year old children: A randomized controlled clinical trial. $\mathrm{J}$ den Res Den Clin Den Prospects. Asvanund Y, Mitrakul K, Juhong R, Arunakul M (2015). Effect of audiovisual eyeglasses during local anesthesia injection in 5-8 year old children. Quintessence International.

Barrios PC, McCombs G, Diawara N, DeLeo G (2015). The use of immersive visualization for the control of dental anxiety during oral debridement. The Journal of Dental Hygiene.

Furman E, Jasinevicius R, Bissada FN, Victoroff ZK, Skillicorn R, Buchner $M$ (2019). Virtual reality distraction for pain control during periodontal scaling and root planning procedures. Journal America Dental Association.

Gao X, Hamzah S, Yiu CKY, Mcgrath C, king NM (2013). Managing dental fear and anxiety in pediatric patient: A qualitative study from the public's perspective. Pediatr Dent.

Jengic V, Pavelic M, Hodak J (2016). Mind the gap between neural and social network-cyberspace and virtual reality in psychiatri and healthcare. Psychiatria Danubina, 28.

Khanapurkar MP, Nagpal ID, Lamba G, Choudhari P, Hotwan K (2018). Effect of virtual reality distraction on pain and anxiety during local anesthesia .injection in children a randomized controlled crossover clinical study. Journal of 
Advanced Medical and Dental Sciences Research.

Laver K, George S, Thomas S, Deutch JE, Crotty M (2012). Cochrane review: virtual reality for stroke rehabilitatiom. Eur J Phys Rehabil Med, ane darabase syst rev.

Niharika P, Venugopal NR, Srujana P, Srikanth K, Daneswari V, Geetha SK (2018). Effects of distraction using virtual reality technology on pain perception and anxiety levels in children during pulp therapy of primary molars. Journal of Indian Society of Pedodontics and Preventive Dentistry.

Pusdatin (2014). Pusat data dan informasi Kementerian Kesehatan Republik Indonesia (Data and information center of the Ministry of Health of the Republic of Indonesia).

Porrit J, Marshman Z, Rodd HD (2012). Understanding children's dental anxiety and psychological approaches to its reduction. Int $\mathrm{J}$ Paediatr Dent.

Shafi S, Mannzoor S, kaushik N (2015). Distraction using virtual reality technology:A review. Int $\mathrm{J} \mathrm{Adv}$ Res 2015; 3: 1465-8

Rober JF, Curzon ME, Koch G, Martens LC (2010). Review: Behavior management techniques in pediatric dentistry. Eur Arch pediatr Dent.

Shetty V, Suresh RL, Hegde MA (2019). Effect of virtual reality distraction on pain and anxiety during dental treatment in 5 to 8 year old children. The Journal of Clinical Pediatric Dentistry, 43(2).

Sullivan C, Schneider PE, Musselman RJ, Dummett CO Jr. Gardiner D (2000). The effect of virtual reality during dental treatment on child anxiety and behavior. ASDC J Dent Child.

Tanja-Dijkstra K, Pahl S, White MP, Andrade J, Qian C, et al (2014). Improving dental experiences by using virtual reality distraction: A simulation study. PloS ONE 9(3): E91276. doi:10.1371/journal.pone.0091276.

Tiwari TS, Thakur R, Agrawal N, Shashikirin NS, Singla S (2015). Evaluation of treatment related fear using a newly developed fear scale for children. Contempt Dent.

Wiederhold MD, Gao K, Wiederhold BK (2014). Clinical use of virtual reality distraction system to reduce anxiety and pain in dental procedures. Cyberpsychol Behav Soc Netw. 